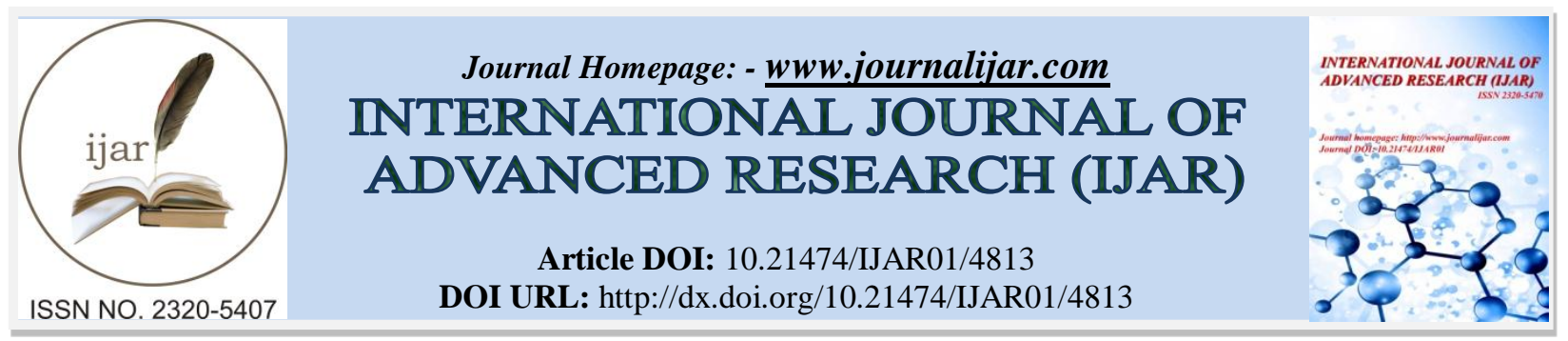

RESEARCH ARTICLE

\title{
ECONOMIC LOSSES ASSOCIATED WITH THE SLAUGHTER OF PREGNANT ANIMALS IN JOS ABATTOIR.
}

Dunka H. $\mathbf{I}^{1}$, Buba D. $\mathrm{M}^{2}$, Gurumyen Y. G ${ }^{2}$, Oragwa A. $\mathrm{O}^{2}$, Oziegbe S. $\mathrm{D}^{3}$ and Patrobas M. $\mathrm{N}^{4}$.

1. Department of Veterinary Public Health and Preventive Medicine, Faculty of Veterinary Medicine, University of Jos, Plateau State, Nigeria.

2. Department of Veterinary Microbiology and Pathology, Faculty of Veterinary Medicine, University of Jos, Plateau State, Nigeria.

3. Department of Veterinary Theriogenology and Production, Faculty of Veterinary Medicine, University of Jos, Plateau State, Nigeria.

4. Department of Veterinary Parasitology and Entomology, Faculty of Veterinary Medicine, University of Jos, Plateau State, Nigeria.

\section{Manuscript Info}

Manuscript History

Received: 11 May 2017

Final Accepted: 13 June 2017

Published: July 2017

Key words:-

cattle, economic, foetus, foetal wastage, goats, slaughter
Abstract

Meat consumption demand is increasing with the growing population; however, livestock foetal wastage in the abattoirs/slaughter slabs in Nigeria is being documented. The trend of slaughtering pregnant animals is against the existing meat edict of 1968 and this accounts for a decrease in livestock production and huge financial losses which invariably affects the livestock economy. Hence, a 5-year retrospective study (2012-2016) was conducted to assess the level of economic implication of foetal wastages in cattle and goats slaughtered in Jos abattoir. The data collected were analyzed using Microsoft Excel, tables, and a graph chart. The total number of cattle and goat slaughtered and their foetuses were reported as documented. A total of 26,242 cattle and 4,612 goats were slaughtered, representing a yearly 5,250 and 922, monthly 437 and 77, and daily 15 and 2.6 averages respectively. Out of these a total of $1,346(4.5 \%)$ and $1,044(22.6 \%)$ fetuses were wasted representing a yearly 269 and 209, monthly 22 and 17 and daily0.75 and 0.6 for cattle and goats respectively. The economic loss associated with the total foetal wastages for cattle and goats in the present study was estimated at $\$ 174,980,000$ (\$571,830.07) and $\$ 10,044,000(\$ 328,235.29)$ respectively. The annual averages of cattle and goat fetal wastage are $\$ 34,970,000(\$ 114,281.06)$ and $\$ 2,090,000(\$ 6,830.07)$ respectively. It is, therefore, necessary to implement the law prohibiting the slaughter of pregnant animals through thorough antemortem inspection which will consequently improve the nation's livestock economy.

Copy Right, IJAR, 2017. All rights reserved.
Corresponding Author:- Dunka H. I.

Address:- Department of Veterinary Public Health and Preventive Medicine, Faculty of Veterinary Medicine, University of Jos, Plateau State, Nigeria. 


\section{Introduction:-}

Meat consumption as a major source of protein, with human beings at the top of the biological chain, is the main reason for livestock husbandry and slaughter activities in every part of the world (Okoli et.al, 2006). The demand for livestock product in developing countries is increasing due to urbanization, changes in lifestyles especially in dietary habits and increasing disposable income. Meat consumption per capita has doubled in developing countries between 1980 and 2002 and this is likely to continue in the near future (Delgado et al., 1999). Both male and female animals are slaughtered at the abattoirs/slaughterhouses for meat and meat products. It is now a trend in the abattoirs to slaughter pregnant animals for meat, rituals, religious festivals, ceremonies, drug formulation, disease control or for financial purposes (Fayemi and Muchenje, 2013; Cadmus and Adesokan, 2010). Food and Agricultural Organization (FAO) estimated that global meat and milk consumption must double by 2050 to meet population growth and it was also estimated that global population will be 9 billion by 2040 (Onteru, et al., 2010; Zakia et al., 2016).

The growth rate of ruminant production is too slow to cope with the per capita requirements in Nigeria, the human population of Nigeria grows with an estimated 3.5\% per year and the livestock resources grow between $0.8 \%$ and 2.9\% per year (Chaudhari and Bokko 2000; Taiwo et al., 2006). The increased demand for animal protein in Nigeria has led to the slaughtering of not only prime breeding males but also pregnant animals resulting in marked fetal wastages in most abattoirs across the country (Oyekunle et al., 1992).

In Nigeria, fetal wastages have been reported by, Abdulkadir et al. (2008) in Markurdi abattoir, Benue State, Ngbede et al. (2012) in Kaduna State and Bello et al. (2008) in Sokoto State, these studies reveal millions of Naira were lost annually due indiscriminate slaughter of pregnant animals. Pregnancy wastage has been reported to account for about 20-25\% of the fall in livestock production in Sub-Saharan Africa (Ngbede et.al., 2012)

A law regulating meat inspection in Nigeria has been in existence to conform to World Health Organization (W.H.O.) directives of 1962, that authorize Veterinarians the world over to be in control of meat inspection and that such duty is transferred to the veterinary department. This law (the meat edict, 1968) took effect in 1968. However, despite the provision of this law, which legally outlawed the slaughter of pregnant animals, the practice with its financial and production implications has continued to thrive in this country. However, Lagos State is currently on the verge of implementing this law (Admin, 2016).

Generally, meat inspection in abattoirs provides useful information regarding the quality of meat. However, abattoir surveys have limitations because the data may have been underestimated because of general poor record keeping (Tembo and Nonga, 2015).

The slaughter of pregnant animals has queried the efficiency of antemortem inspections at the abattoir, proved the need for well-equipped Veterinary services for improved herd health management in the state and has frustrated the efforts of livestock husbandry system in increasing animal production to meet the growing demand for animal protein by a growing human population. (Chaudhari and Paul-Bokko, 2000; Addass et al., 2010; Ngbede et al., 2012). This report is intended to evaluate the magnitude of fetal wastages and to assess the economic losses associated with it.

\section{Materials and Methods:-}

Study area and data Collection:-

A retrospective study was carried out using Jos abattoir records for cases of foetal losses in cattle and goats over a period of five years $(2012$ - 2016). Jos is the capital city of Plateau State is located in the North-Central geo-political zone of Nigeria. It is comprised of three local government areas: Jos East, Jos North and Jos South with coordinates between latitude $9^{\circ} 56^{\prime}$ North and longitude $8^{\circ} 53^{\prime}$ East, having a total land area of $1,821 \mathrm{~km}^{2}$. Plateau State is the $12^{\text {th }}$ largest State in Nigeria with a population of about three million people. The State capital has only one registered abattoir which is the Jos abattoir, and it was established in 1975.

\section{Data Analysis:-}

The data were analyzed and presented using descriptive statistics such as tables and a graph chart. Economic analysis of losses from fetal wastage was calculated as described by Ngbede et al. (2012). 


\section{Results:-}

A total of 1,346 cattle and 1,044 goat fetuses from a total of 26,242 and 4,612 slaughtered animals respectively were documented within the 5-year study period (Table 1). Yearly, total slaughtered figure was highest in 2013 for cattle $(6,302)$ and in 2012 for goats $(1,125)$, while it was lowest in 2015 for both cattle $(4,405)$ and goats $(750)$. A total number of cattle and goats slaughtered at Jos abattoir and the trend of fetal wastages in both species is shown in Figure 1.
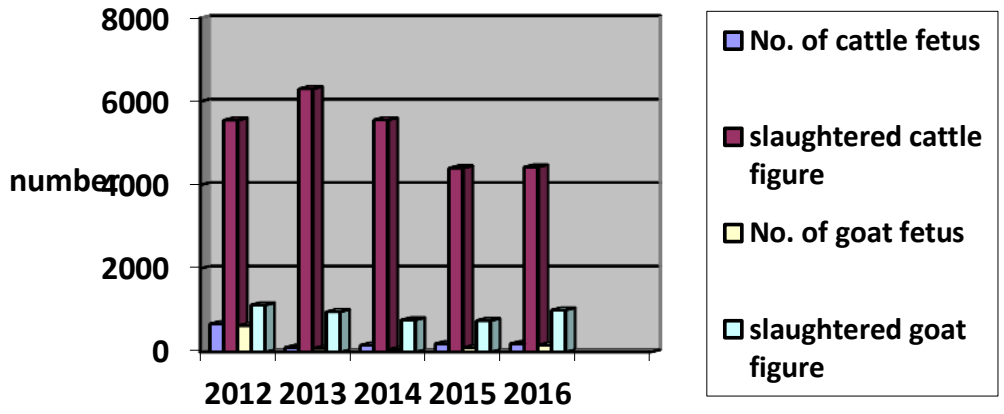

years

Figure 1:- An Annual figure of slaughtered animals and fetuses (2012-2016).

Table 1:- An Annual Record of slaughtered animal and fetuses with an estimate of financial losses in Jos abattoir (2012-2016).

\begin{tabular}{|c|c|c|c|c|c|c|}
\hline & 2012 & 2013 & 2014 & 2015 & 2016 & Total \\
\hline Total sl. cattle & 5,553 & 6,302 & 5,558 & 4,405 & 4,430 & 26,248 \\
\hline No. of cattle & 675 & 112 & 163 & 197 & 199 & 1,346 \\
\hline foetus & 2.2 & 1.8 & 2.0 & 9.0 & 4.5 & 4.5 \\
\hline $\begin{array}{l}\text { Pr. of cattle foetal } \\
\text { wastage }(\%)\end{array}$ & $8: 1$ & $56: 1$ & $34: 1$ & $22: 1$ & $22: 1$ & $20: 1$ \\
\hline Ratio of sl. cattle & & & & & & \\
\hline to foetus & $87,750,000$ & $14,560,000$ & $21,190,000$ & $25,610,000$ & $25,870,000$ & $174,980,000$ \\
\hline Amount of loss & 1,125 & & & 750 & 1,004 & 4,612 \\
\hline & 629 & 89 & 57 & 108 & 163 & 1,044 \\
\hline Total sl. goats & 55.9 & 9.2 & 7.4 & 14.4 & 16.2 & 22.6 \\
\hline foetus & $2: 1$ & $11: 1$ & $14: 1$ & $7: 1$ & $6: 1$ & $4: 1$ \\
\hline $\begin{array}{l}\text { Pr. of goats foetal } \\
\text { wastage }\end{array}$ & $6,290,000$ & 890,000 & 570,000 & $1,080,000$ & $1,630,000$ & $10,044,000$ \\
\hline $\begin{array}{l}\text { Ratio of sl. goats } \\
\text { to foetus }\end{array}$ & & & & & & \\
\hline $\begin{array}{l}\text { Amount of loss } \\
\text { (N) }\end{array}$ & & & & & & \\
\hline $\begin{array}{l}\text { sl. - slaughter } \\
\text { pr. - proportion }\end{array}$ & & & & & & \\
\hline
\end{tabular}

On the average, the number of cattle and goats slaughtered monthly was 437 and 77 respectively (Table 2) and the cattle and goat fetuses obtained were 22 and 17 respectively. The proportion of fetal wastage for the study period was $4.5 \%$ in cattle and $22.6 \%$ in goats (Table 2). The highest proportion of fetal wastage was observed in 2012 in both cattle $(12.2 \%)$ and goat $(55.9 \%)$ while the lowest proportion $(1.8 \%)$ for cattle fetal wastage was recorded in 2013 and that for goat (7.4\%) was in 2014. Financial losses over the 5-year period due to the wastage of 1,346 cattle and 1,044 goat fetuses when the cost of an average adult cow and goat is 130,000 and 10,000 (Dunka, H. I, personal communication) respectively is $\$ 174,980,000$ and $\$ 10,044,000$ respectively (Table 2). 2012 recorded the highest fetal wastage in cattle and goat with a value of $\$ 87,750,000$ and $\$ 6,193,000$ respectively. $\$ 14,560,000$ was the lowest amount recorded for cattle in 2013 while $\$ 570,000$ was obtained for goats in 2014 . 
Table 2:- Average daily, monthly and yearly slaughtered cattle and goat, their fetuses' figures and the financial implications.

\begin{tabular}{|l|l|l|l|}
\hline & Daily & Monthly & Yearly \\
\hline Total sl. cattle & 15 & 437 & 5,250 \\
Cattle foetal loss & 0.75 & 22 & 269 \\
Amount (N) & 97,500 & $2,860,000$ & $34,970,000$ \\
Amount (\$) & 229.5 & 6,732 & 82,314 \\
Total sl. goats & 2.6 & 77 & 922 \\
Goats foetal loss & 0.6 & 17 & 209 \\
Amount (N) & 6,000 & 170,000 & $2,090,000$ \\
Amount (\$) & 183.6 & 5,202 & 63,954 \\
\hline
\end{tabular}

sl. - slaughtered

\section{Discussion:-}

The total number of cattle and goats slaughtered at Jos abattoir during the study period was 26,248 and 4,612 respectively. The yearly average of 5,250 and 922, a monthly average of 437 and 77 and a daily average of 15 and 2.6 were observed in cattle and goats respectively. This result agrees with the findings of Sini et al. (2012) that reported a daily slaughter of 15 cattle and a higher daily slaughter of 20 goats in the same abattoir. The disparity could be because of the prospective study carried out by the latter in which data were collected by the researchers themselves as compared with this retrospective study. Aniebo et al., (2009) reported the same disparity in Rivers State, Nigeria, where he cited a daily slaughter figure of 18 cattle and 11 goats in contrast to the records at the State Ministry of Agriculture which showed that 6 cattle and no goats were inspected and slaughtered daily at the same slaughterhouse. The monthly averages of slaughtered cattle reported in this study were higher than the 174 (40.6 weekly) in Lafia abattoir (Idahor et al., 2009) but comparatively, lower than 3,778 in Lafenwa abattoir, Abeokuta (Oduguwa et al., 2013). The annual mean of slaughtered goat (922) was lower than 22,099 in Minna Municipal Abattoir (Alhaji and Odetokun, 2013).

Result from this study suggests that fetal wastage is a common finding and it is recorded almost daily across abattoirs in Nigerian abattoirs (Bello et al., 2008; Abdulkadir et al., 2008; Oduguwa et al., 2013; Ardo et al., 2013 and Odeh et al., 2015). The proportion of cattle and goat fetal wastage expressed as the total number of fetuses documented divided by the total number of cattle and goats slaughtered was $4.5 \%$ and $22.6 \%$ respectively. This figure is higher than the value reported by Muhammad et al. (2008) in cattle (3.0\%) and the report by Mshelia et al., (2015) in goats (13\%). However, this was lower than the 10.7\% reported by Oduguwa et al., (2013) and $8.1 \%$ by Fayemi et al. (2008) for cattle. The higher fetal wastage reported in this study could be as a result of cattle rustling in and around the State (France-Presse, 2010 and Idegu, 2014). This showed that on the average, one fetus is lost for every twenty cattle (20:1) and one fetus for every four goats (4:1) slaughtered. These figures agrees with the reports of 20:1 by Oyekunle et al. (1992) and 19:1 by Fayemi et al. (2008) but was lower than the 9:1 findings of Oduguwa et al. (2013) in cattle, while Idahor et al. (2009) reported foetal loss in every 25 does slaughtered. The high ratio recorded for goats was possibly due to their twinning and rarely multiple births of does compared to cows. The overall higher fetal wastage may be due to the slaughtering of pregnant animals for the purposes of festivals, ceremonies, disease and poverty (Oduguwa et al., 2013).

The financial implications of fetal wastage in this study indicate economic and production losses. Assessing the economic impact of slaughtering pregnant cows and does at Jos abattoir, where an average cattle and goat costs $\$ 130,000.00(\$ 424,84)$ and $\$ 10,000.00$ (\$32.68) is $\$ 174,980,000(\$ 571,830.07)$ and $\$ 10,044,000(\$ 32,823.53)$ respectively for the 5-year study period. Annually, $\$ 34,970,000$ for cattle and $\$ 2,090,000$ for goats are lost in one State. These economic losses are comparable to an estimated $\mathrm{N} 8,353,800.00(\$ 56,828.57)$ for calf fetal wastage and $\mathrm{N} 104,362,830.00(\$ 652,267.69)$ from 2,862 kid fetal wastages at the Minna slaughterhouse reported in a 10-year survey by Alhaji (2011). Mshelia et al., (2015) reported an estimated annual economic value of $\$ 302,400.00$ for cattle and $\$ 257,040.00$ for goats wasted in Maiduguri. The indiscriminate slaughters of pregnant animals seen in this and other studies have shown to be occurring nationwide. This clearly undermines the implementation of existing laws and the efficacy of antemortem inspection in Nigerian abattoirs. The result of this study when estimated for cattle and goats in the 36 States of Nigeria and the Federal Capital Territory annually, shows that about $\$ 1,293,890,000(\$ 4,228,398.69)$ and $\$ 77,330,000$ (\$252,712.42) would be lost respectively. This gross production loss if not curbed is presumably going to affect the security of future animal protein sources when human population increases as predicted by FAO (Onteru, et al., 2010; Zakia et al., 2016). Effective implementation of this law, a high 
fine for defaulters and strict antemortem meat inspection in abattoirs and slaughter slabs to isolate pregnant animals will eliminate fetal wastages and boost animal production nationwide.

\section{Conclusion:-}

From the findings of this present study, foetal wastages were observed in both bovine and caprine species and the rate is higher in goats than cattle. Such wastages impair the livestock production industry and account for huge financial losses. In order to forestall such occurrences, it is recommended that Nigerian meat edict is implemented nationwide and abattoirs/slaughter slabs are equipped with facilities, modern equipment and sufficient Veterinarians for competent services. Livestock farmers should be educated on the laws prohibiting the slaughter of pregnant animals with the consequent production losses and the labeling of meats from pregnant animals for consumer discretion.

\section{References:-}

1. Abdulkadir, U., Jiya, E. Z., \&Kosu, S. A. (2008). Survey of foetal wastages: a case study of Makurdi abattoir in Benue state from 1997 to 2002. Pakistan Journal of Nutrition, 7(3), 450-452.

2. Addass, P.A., Midau, A., Milka, M. and Tizhe, M.A. 2010. Assessment of abattoir foetal wastage of cattle, sheep and goat in Mubi main abattoir, Adamawa State, Nigeria. World J Agricul Sci, 6(2): 132-137.

3. Admin. (2016). It is illegal to slaughter pregnant animals - Agric Comm.National Daily. nationaldailyng.com > Business > Agribusiness

4. Alhaji, N. B. (2011): Prevalence and economic implication of calf fetal wastage in an abattoir in north central Nigeria. Tropical Animal Production and Animal Genetic Training Resource.

5. Alhaji, N. B, Odetokun, I. A. (2013). Food security and economic implications of small ruminant fetal wastages in Nigeria: a case of an abattoir. Liv. Res. Rur. Dev., 25(79).

6. Aniebo, A. O., Wekhe, S. N., \& Okoli, I. C. (2009). Abattoir blood waste generation in Rivers State and its environmental implications in the Niger Delta. Toxicological \& Environmental Chemistry, 91(4), 619-625.

7. Bello, M. B., Garba, H. S., and Sonfada, M. L. (2008). Foetal wastage in camels slaughtered at Sokoto municipal abattoir. Sokoto Journal of Veterinary Sciences, 7(1).

8. Cadmus, S.I.B. and Adesokan, H.K. (2010). Bovine fetal wastage in Southwestern Nigeria: A survey of some Abattoirs. Trop. Anim. Hlth. Prod. 42(4),617-621

9. Chaudhari, S.U.R., Paul-Bokko, B., 2000. Reproductive status, pregnancy wastage and incidence of gross genital abnormalities in cows slaughtered at Maiduguri abattoir, Nigeria. Pakistan Vet. J. 20(4), 203-205.

10. Delgado, C., Rosegrant, M., Steinfeld, H., Ehui, S. And Courbois, C. (1999) "Livestock to 2020 - The Next Food Revolution". Food, Agriculture and the Environment Discussion Paper 28. IFPRI/FAO/ILRI

11. Fayemi, P. O., \&Muchenje, V. (2013). Maternal slaughter at abattoirs: history, causes, cases and the meat industry. SpringerPlus, 2(1), 125.

12. Fayemi, A.O., Taiwo, B.B.A., Okubanjo A.O., and Adekunmisi, A.A. (2008). Frequency of slaughtering gravid cows in some selected parts of Ogun State. Proceedings of the 33rd Annual Conference of the Nigeria Society of Animal Production. September, 2008. Ayetoro pp $234-237$.

13. France-Presses, A. (2010). Cattle thefts sparked deadly Nigeria massacre. The Sydney morning herald. www.smh.com.au > World

14. Idahor, K.O., Omeje, J.N., Agu, V.E., Audi, P., David, R.S., and Luka, D.B. (2009): Awareness of foetal losses from ruminants slaughtered at Lafia abattoir. Journal of Life Physical Science, 3:44-48.

15. Idegu, Y. A. (2014). Plateau: From ethnic crises to cattle rustling. The Nation. thenationonlineng.net/plateauethnic-crises-cattle-rustling

16. Mshelia, G. D., Maina, V. A., \& Aminu, M. D. (2015). Foetometrics and Economic Impact Analysis of Reproductive Wastages in Ruminant Species Slaughtered in North-Eastern Nigeria. Journal of Animal Production Advances, 5(4), 645-653.

17. Muhammed, B.F., Haruna, A.M. and Bichi, J.M. (2008). Foetal wastage in Northern Nigeria. The case of Gombe Abattoir. Proceedings of the 13th Annual Conference of the Animal Science Association of Nigeria. September 15 - 19, 2008. Ahmadu Bello University, Zaria pp 124 -127.

18. Ngbede, E.O., Hena, S. A., Tarhyel, R., \&Bulus, C. (2012). Bovine foetal wastage and its economic implication: a six-year (2003-2008) retrospective study in an abattoir in northwestern, Nigeria. Scientific Journal of Veterinary Advances, 1(2), 42-46.

19. Odeh, S., Dawuda, P., Oyedipe, E., \& Obande, G. (2015). Incidence of foetal wastage in slaughtered cattle at Wurukum abattoir, Makurdi, Benue State. Vom Journal of Veterinary Sciences, 10(1), 41-50. 
20. Oduguwa, B. O., Raimi, C. O., Talabi, A. O., \& Sogunle, O. M. (2013). Fetal losses from slaughtering pregnant cows at Lafenwa abattoir in Abeokuta, South Western Nigeria. Global Journal of Biology, Agriculture and Health Sciences, 2(2), 38-41.

21. in Developing Countries. Biotechnology and Genetic Engineering Reviews. Vol 27, 217-228.

22. Okoli, G., Okoli, C., Okorondu, V., \& Opara, M. (2006). Environmental and public health issues of animal food products delivery system in Imo State, Nigeria. Online Journal Of Health And Allied Sciences, 5(2)

23. Onteru S.K., Amoaire, A. and Rothschild, M.F. (2010). Biotechnology Developments in Livestock Sector

24. Oyekunle MA, Olubanjo OO, Fasina OE (1992). Foetal wastage in abattoirs and its implication: situation report from Ogun State, Nigeria. Nigerian J. Anim. Prod., 19: 57-63.

25. Sini, T. I., Owolodun, O., \& Leo, E. (2012). Abattoir Management: A case report of a local abattoir in Jos South, Plateau State, Nigeria. Vom Journal of Veterinary Sciences, 9(1), 40-46.

26. Taiwo, B.B.A., Aluko, F.A and Olufowobi, O.A. (2006). Reproductive wastage in some urban abattoirs in Ogun State. Proceedings of the 31st Annual National Conference of the Society for Animal Production, Kano. Pp. 140-143.

27. Tembo, W., \&Nonga, H. E. (2015). A survey of the causes of cattle organs and/or carcass condemnation, financial losses and magnitude of foetal wastage at an abattoir in Dodoma, Tanzania. Onderstepoort Journal of Veterinary Research, 82(1), 01-07.

28. Zakia L.G. and David W. Pascual (2016). Brucellosis Vaccine for Livestock. Veterinary Immunology and Immunopathology. Elsevier hlt://dx.doi.org/10.1016.j.vetmm.2016.03.011. 